\title{
Cadmium and Lead Cloud Point Preconcentration and Determination in Tobacco Samples by Thermospray Flame Furnace Atomic Absorption Spectrometry
}

\author{
Frank P. Andrade, Clésia C. Nascentes and Letícia M. Costa* \\ Departamento de Química, Universidade Federal de Minas Gerais, 31270-901 Belo Horizonte-MG, Brazil
}

\begin{abstract}
A espectrometria de absorção atômica com forno tubular na chama (TS-FF-AAS) foi empregada para a determinação de $\mathrm{Cd}$ e $\mathrm{Pb}$ em diferentes tipos de amostras brasileiras de tabacos após a préconcentração no ponto nuvem (CP) otimizada por planejamento Doehlert. Para a separação das fases no procedimento por ponto nuvem, Triton ${ }^{\circledR}$ X-114 e 2-(bromo-2-piridilazo)-5-dietilaminofenol (Br-PADAP) foram utilizados como surfactante não iônico e agente complexante, respectivamente. Cádmio e chumbo foram determinados após digestão ácida e pré-concentração por ponto nuvem, sendo que as variáveis otimizadas por planejamento Doehlert foram: volume do agente complexante, volume de Triton ${ }^{\circledR}$ X-114 e pH. Um ponto de máximo foi obtido nas superfícies de resposta para $\mathrm{Cd}$ e $\mathrm{Pb}$. Para as determinações dos elementos por TS-FF-AAS, um volume de amostra de $50 \mu \mathrm{L}$ foi introduzido no tubo de Ni posicionado sobre a chama, usando ar como carregador na vazão de $0,4 \mathrm{~mL} \mathrm{~min}^{-1}$. Os limites de detecção e os desvios padrão relativos após a combinação de $\mathrm{CP}$ e TS-FF-AAS foram de 4,0 e $13 \mu \mathrm{g} \mathrm{kg}^{-1}$ e 3,1 e 0,7\% para $\mathrm{Cd}$ e $\mathrm{Pb}$, respectivamente. A exatidão do método proposto foi avaliada realizando-se testes de adição-recuperação e empregando-se material de referência certificado (folhas de chá e folhas de pessegueiro). As recuperações variaram de 93 a 103 e 93 a 107\% para $\mathrm{Cd}$ e $\mathrm{Pb}$, respectivamente. Todos os resultados obtidos para as amostras dos materiais de referência estão em concordância com os valores certificados a um nível de confiança de 95 ou $99 \%$ aplicando-se o teste $t$-Student.
\end{abstract}

A thermospray flame furnace atomic absorption spectrometer (TS-FF-AAS) was employed to determine $\mathrm{Cd}$ and $\mathrm{Pb}$ in different Brazilian tobacco samples. Sample pretreatment consisted of acid decomposition and cloud point $(\mathrm{CP})$ preconcentration optimized by Doehlert design. To promote phase separation in the cloud point procedure, polyoxyethylene (8) isooctylphenyl ether (Triton ${ }^{\circledR}$ X-114) and 2-(bromo-2-pyridylazo)-5-diethyl-amino-phenol (Br-PADAP) were used as a nonionic surfactant and a complexing agent, respectively. The variables of the cloud point preconcentration procedure optimized by Doehlert design were: complexing agent volume, Triton $\mathrm{X}-114$ volume, and $\mathrm{pH}$. A response surface maximum point was obtained for $\mathrm{Cd}$ and $\mathrm{Pb}$. For TS-FF-AAS, a sample volume of $50 \mu \mathrm{L}$ was introduced into the hot Ni tube using air carrier at a flow rate of $0.4 \mathrm{~mL} \mathrm{~min}^{-1}$. The limits of detection and relative standard deviations obtained for $\mathrm{Cd}$ and $\mathrm{Pb}$ when $\mathrm{CP}$ and TS-FF-AAS were associated were 4.0 and $13 \mu \mathrm{g} \mathrm{kg}{ }^{-1}$, and 3.1 and $0.7 \%$, respectively. Accuracy was checked by addition-recovery experiments, as well as by using two certified reference materials (tea and peach leaves). Cadmium and lead recoveries ranged from 93 to 103 and 93 to $107 \%$, respectively. All results obtained for reference materials were in agreement with certified values at 95 or $99 \%$ confidence levels by $t$-Student test.

Keywords: tobacco, acid digestion, cloud point preconcentration, Doehlert design, TS-FF-AAS

\section{Introduction}

The relevance of trace metals in biological samples derives from their essentiality, as well as from their potentially toxic effects in living organisms. An example of a toxic trace metal in biological systems that has

\footnotetext{
*e-mail: leticia@qui.ufmg.br
}

no biological function in humans is lead, a cumulative metabolic poison with physiological and neurological effects. ${ }^{1}$ Lead has carcinogenic properties and interferes with the resistance to infectious diseases. ${ }^{2}$ Another metal that has no biological function in the human body is cadmium, which, depending on its concentration, can affect all forms of life as well. Chronic exposure to $\mathrm{Cd}$ can induce damages to the kidneys, lungs, heart, bones, 
and gonads. ${ }^{2}$ This metal can gradually accumulate in the human body, producing a number of adverse health effects, such as nephrotoxicity and osteotoxicity. ${ }^{1}$ The toxicity of $\mathrm{Pb}$ and $\mathrm{Cd}$ in biological fluids has been reported, especially concerning the determination of safe concentration intervals and overexposure effects. Acceptable concentrations of $\mathrm{Pb}$ and $\mathrm{Cd}$ in human blood are below 100 and $10 \mu \mathrm{g} \mathrm{L}^{-1}$, respectively, depending on the subject's age and gender; however, individual sensitivity to biological exposure varies. $^{2}$

Cadmium and lead are present in tobacco samples. Cadmium is the best-studied metal in cigarette smoke and smoking is the main source of Cd intake by humans. ${ }^{3}$ In contrast, smoking is not the main source of $\mathrm{Pb}$ intake by humans, but its contribution has become increasingly relevant. The ability of plants like Nicotiana tabacum to accumulate metals is utilized by modern biotechnology to decontaminate soils. However, with respect to tobacco farming for cigarette production, this ability poses a health threat. In fact, toxic metals, such as $\mathrm{Al}, \mathrm{Cd}, \mathrm{Cr}, \mathrm{Cu}, \mathrm{Pb}$, $\mathrm{Hg}, \mathrm{Ni}$, and $\mathrm{Zn}$, are found in tobacco, cigarette paper and filter, and cigarette smoke. The role of these metals in the pathophysiology of diseases caused by cigarette smoking is poorly understood. Emerging data suggest that the alteration of metal homeostasis in the human body by cigarette smoking plays a crucial role in the genesis of a number of diseases. ${ }^{3}$

Modern analytical chemistry is characterized by hyphenated analytical techniques that involve the combination of sensitive components to improve detection, as recently proposed by $\mathrm{Wu}$ et $a l .{ }^{4}$ Sometimes, a preconcentration step helps to solve sensitivity problems, such as low analyte concentrations in actual samples or high concentration of matrix interferents present in complex samples, especially in biological ones. ${ }^{5}$

Cloud point extraction (CPE) is a separation and preconcentration procedure that has been extensively applied in the determination of trace metal ions in several matrices. ${ }^{6,7}$ Its main advantages are its low cost, simple experimental procedure, high preconcentration factors, and environmental and personal safety. ${ }^{8}$ Cloud PE is based on the property of most nonionic surfactants in aqueous solutions to form micelles and become turbid when heated to cloud point temperature, above which the micellar solution separates into a small volume surfactant-rich phase and a diluted aqueous phase with surfactant concentration close to the critical micellar concentration (CMC). ${ }^{9}$ Its main limitation is the relatively low partition coefficients of several metal species with determined chelates. However, this can be circumvented with the use of highly hydrophobic ligands. ${ }^{10}$
Several analytical techniques, such as molecular absorption spectrophotometry, flame atomic absorption spectrometry (FAAS), inductively coupled plasma mass spectrometry (ICP-MS), graphite furnace atomic absorption spectrometry (GF AAS), and inductively coupled plasma optical emission spectrometry (ICP OES), have been used to determine metals in micellar phase with sensitivity in most applications. Although previous results have shown that the FAAS detection limits are incompatible with determination at sub $\mu \mathrm{g} \mathrm{L}^{-1}$ levels, depending on the matrix, the detection limits can be improved. ${ }^{11}$ With this point in view, since Gáspár and Berndt ${ }^{11}$ proposed thermospray flame furnace atomic absorption spectrometry (TS-FFAAS), its sensitivity to trace levels for different elements has been improved. ${ }^{12}$ The association of CPE procedures and TS-FF-AAS has been used in the last years in the direct determination of some metals in liquid samples. ${ }^{13-16}$

TS-FF-AAS achieves complete sample introduction and increases the concentration of the atoms in the optical path. This technique is based on the atomization of the species through the formation of a thermospray at the end of a ceramic capillary inserted into a hot Ni tube located on the FAAS burner. ${ }^{17,18}$ The tip of the ceramic capillary penetrates the sampling hole, resulting in a very high temperature gradient. The sensitivity for different elements is increased up to two orders of magnitude. ${ }^{11,16,17}$ Slurry sample introduction, ${ }^{1,18}$ direct sample introduction, ${ }^{14,19,20}$ preconcentration methods using CPE, ${ }^{12,21}$ and solid sorbents ${ }^{6,22}$ are some strategies that are applied with TS-FF-AAS.

The aim of this work was to develop an analytical procedure employing $\mathrm{Cd}$ and $\mathrm{Pb}$ separation and preconcentration by cloud point methodology for their determination in Brazilian tobaccos by thermospray flame furnace atomic absorption spectrometry (TS-FF-AAS).

\section{Experimental}

\section{Instruments}

A Perkin Elmer Model AAnalyst 200 flame atomic absorption spectrometer (Norwalk, USA) equipped with a deuterium lamp background correction system was used. Electrodeless discharge lamps were used in the determination of $\mathrm{Cd}$ and $\mathrm{Pb}$. The wavelength and spectral band pass were set at 283.3 and $0.7 \mathrm{~nm}$ for $\mathrm{Pb}$ and 228.8 and $0.7 \mathrm{~nm}$ for $\mathrm{Cd}$. An acetylene flow rate of $2.5 \mathrm{~L} \mathrm{~min}^{-1}$ was used with an air flow rate of $10.0 \mathrm{~L} \mathrm{~min}^{-1}$. The FAAS instrumental parameters were adjusted according to the manufacturer's recommendations.

In the TS-FF-AAS determinations were used a system with one six-channel peristaltic pump (Ismatec, 
Labortechnik Analytik, Glattbrugg-Zürich, Switzerland) furnished with Tygon tubes, a lab-made commuting injector, and a thermospray flame furnace unit, which included the ceramic capillary $(0.5 \mathrm{~mm}$ i.d., $2.0 \mathrm{~mm}$ 0.d., and $100 \mathrm{~mm}$ in length) and a Ni tube $(10 \mathrm{~cm})$. The tube was located on the burner, laid on four ceramic fixed pins of a lab-made stainless steel support and could be moved in and out of the flame. To reach the proper atomization temperature for $\mathrm{Cd}$ and $\mathrm{Pb}$ inside the tube, six 2-mm diameter holes were drilled on the bottom of the tube. Another hole was drilled at $90^{\circ}$ to the bottom holes for inserting the thermospray capillary. The capillary tip was set about $1 \mathrm{~mm}$ inside the tube furnace. The manifold was assembled with $0.5-\mathrm{mm}$ i.d. PTFE tubing. ${ }^{13}$

The samples were prepared using a muffle furnace (Quimis, Q318M, Diadema, SP, Brazil), a hot plate (Tecnal, 1E085 Piracicaba, SP, Brazil), a centrifuge (Janetzki T32, Berlin, Germany), a domestic microwave oven (Panasonic, São Paulo, SP, Brazil), and a pHmeter (Digimed DM20 São Paulo, SP, Brazil).

\section{Reagents and solutions}

All solutions were prepared using analytical grade reagents (Merck, Darmstadt, Germany) and distilled and deionized water (Druckfester MischbettWasservollentsalzer, DI800, Munich, Germany). The laboratory glassware was kept overnight in $10 \% \mathrm{v} / \mathrm{v}$ nitric acid solution, rinsed with deionized water, and dried in a dust-free environment before use.

Reference solutions of $\mathrm{Cd}$ and $\mathrm{Pb}$ were prepared daily by diluting $1000 \mathrm{mg} \mathrm{L}^{-1}$ stock solution with $1 \% \mathrm{v} / \mathrm{v} \mathrm{HNO}_{3}$ solution. A $1.0 \mathrm{mmol} \mathrm{L}^{-1}$ solution of Br-PADAP in 5.0\% $(\mathrm{m} / \mathrm{v})$ Triton ${ }^{\circledR}$ X-114 (Sigma-Aldrich, St. Louis, MO, USA) solution was prepared by dissolving $36.0 \mathrm{mg}$ of 2-(bromo2-pyridylazo)-5-diethyl-amino-phenol (Br-PADAP) in water and adding $5.0 \mathrm{~g}$ of nonionic surfactant. The volume was completed to $100.0 \mathrm{~mL}$ with distilled-deionized water. A buffer solution with $\mathrm{pH} 9$ was prepared by mixing $50.0 \mathrm{~mL}$ of $0.1 \mathrm{~mol} \mathrm{~L}^{-1} \mathrm{H}_{3} \mathrm{BO}_{3} / \mathrm{KCl}$ and $21.5 \mathrm{~mL}$ of $0.1 \mathrm{~mol} \mathrm{~L}^{-1} \mathrm{NaOH}$. The $\mathrm{pH}$ was adjusted using $0.5 \mathrm{~mol} \mathrm{~L}^{-1}$ $\mathrm{NaOH}$ and the volume was completed to $100.0 \mathrm{~mL}$ with distilled-deionized water. The viscosity of the micellar phase was reduced using a $0.1 \mathrm{~mol} \mathrm{~L}^{-1} \mathrm{HNO}_{3}$ in ethanol $90 \%(\mathrm{v} / \mathrm{v})$ diluent solution.

\section{Samples}

Different Brazilian tobacco samples (regular cigarettes, tobacco rolls, and straw cigarettes) manufactured by different companies bought at a local market in Belo
Horizonte, Minas Gerais, Brazil were analyzed using TSFF-AAS.

The accuracy of the proposed method was checked with standard reference materials, tea leaves (GBW 08505) and peach leaves (GBW 08501), produced by the Research Center for Eco-Environmental Sciences (Beijing, China).

\section{Ash and wet digestion procedure}

A mass of $500 \mathrm{mg}$ of tobacco samples was mineralized at $450{ }^{\circ} \mathrm{C}$ for $6 \mathrm{~h}$, until a white ash was obtained. The residue was treated with $2.0 \mathrm{~mL}$ of concentrated nitric acid and evaporated to dryness before heating at $450{ }^{\circ} \mathrm{C}$ for $30 \mathrm{~min}$. The cooled residue was moistened with water and dissolved in $1.0 \mathrm{~mL}$ of concentrated hydrochloric acid and water. After cooling, the colorless solution was made up to $25.0 \mathrm{~mL}$ with water. ${ }^{23}$

As previously mentioned, all solutions were prepared using analytical grade reagents and distilled and deionized water.

\section{Cloud point extraction procedure for the determination of $\mathrm{Cd}$ and $\mathrm{Pb}$ by TS-FF-AAS}

The preconcentration procedure addition sequence for $\mathrm{Cd}$ and $\mathrm{Pb}$ was as follows: $10.0 \mathrm{~mL}$ of sample, $1.0 \mathrm{~mL}$ buffer solution pH 9.0, Br-PADAP solution (1.0 $\left.\mathrm{mmol} \mathrm{L}^{-1}\right)$, and Triton ${ }^{\circledR} \mathrm{X}-114$ solution $5.0 \%(\mathrm{~m} / \mathrm{v})$. The solution was placed in a domestic microwave oven at $10 \%$ of the maximum power to accelerate the formation of micelles in the cloud point preconcentration procedure and to prevent sample loss, as discussed by Bezerra et al. ${ }^{10}$

The separation of the micellar phase from the aqueous phase was accelerated by centrifuging the solution for $10 \mathrm{~min}$ at $2500 \mathrm{rpm}$. The solution was cooled in an ice bath and kept in it for $15 \mathrm{~min}$. The micellar phase became viscous and the aqueous phase was removed by inverting the container. In the last step, $0.5 \mathrm{~mL}$ of diluent was added to the separated micellar phase. After the addition of the nitric acid/ethanol solution, $50 \mu \mathrm{L}$ of the micellar phase was introduced into the spectrometer through the sampling system and the analytical signals were recorded in integrated absorbance.

Optimization procedure for $\mathrm{Cd}$ and $\mathrm{Pb}$ cloud point extraction applying Doehlert design

Based on previously reported data, ${ }^{8,24}$ some experiments were made using PAN (piridylazonaftol) and Br-PADAP as complexing agents in the cloud point preconcentration 
procedure. In TS-FF-AAS, the best atomic absorbance signals were obtained employing Br-PADAP. Thus, the optimization study was performed with Br-PADAP.

The preconcentration cloud point procedure was optimized using a Doehlert design in association with response surface methodology (RSM). A Doehlert matrix is a second-order design that can be drawn with two, three, or more variables or factors. ${ }^{25,26}$ It allows identifying critical points (maximum, minimum, and saddle points) at each step of the optimization process and consists of an experimental design in which a set of points is uniformly distributed in a spherical lattice (in a case of three variables). The whole experimental domain is assayed with a minimum number of experiments following a sequential approach. For a k number of factors, $\left(\mathrm{k}^{2}+\mathrm{k}+1\right)$ experiments are required. ${ }^{27}$ According to the Doehlert design for three variables, the factors $\mathrm{pH}$ and final concentration of the Br-PADAP solution were studied at five levels. The final concentration of the Triton ${ }^{\circledR}$ X-114 5.0\% (m/v) solution was studied at three levels. Table 1 shows the design matrix for the optimization experiments of these variables with laboratory values, along with coded values in parentheses. The $\mathrm{pH}$ was studied in the 7.0-11.0 range. The final concentration of Br-PADAP was studied using volumes ranging from 50 to $450 \mu \mathrm{L}$, whereas the final concentration of the Triton ${ }^{\circledR}$ $\mathrm{X}-1145.0 \%(\mathrm{~m} / \mathrm{v})$ solution was studied using volumes from 50 to $1050 \mu \mathrm{L}$.
The experimental data were processed using the Statistica $^{\circledR}$ software. ${ }^{28}$

\section{Results and Discussion}

$C P$ preconcentration optimization of the experimental conditions using Doehlert design

The CP preconcentration conditions were optimized using $50.0 \mu \mathrm{g} \mathrm{L}^{-1} \mathrm{Cd}$ and $\mathrm{Pb}$ reference solutions. Air was used as a carrier to avoid the pronounced dispersion observed at the solution-carrier interface. ${ }^{19,20}$ The flow rate used to introduce $50 \mu \mathrm{L}$ of the micellar solution into the hot $\mathrm{Ni}$ tube was $0.4 \mathrm{~mL} \mathrm{~min}^{-1}$. Flow rates higher than $0.65 \mathrm{~mL} \mathrm{~min}^{-1}$ may reduce the sensitivity, because the residence time of the liquid in the heated capillary tip is too short for evaporation to occur. ${ }^{9}$

In the Doehlert design, variables $\mathrm{pH}$, complexing agent, and surfactant volumes were optimized according to the coded and real values described in Table 1. This table also presents the integrated absorbance and peak height values for $\mathrm{Cd}$ and $\mathrm{Pb}$ metal ions. Figures 1 and 2 present the $\mathrm{Cd}$ and $\mathrm{Pb}$ surface responses, respectively, and the relationship between the $\mathrm{pH}$ and the Triton ${ }^{\circledR}$ $\mathrm{X}-114$ volume. The statistical program allowed plotting two-dimensional graphs. Maximum points were obtained for all surface responses, including those obtained with

Table 1. Doehlert design and integrated absorbance for $\mathrm{Cd}$ and $\mathrm{Pb}$ after $\mathrm{CPE}+\mathrm{TS}-\mathrm{FF}-\mathrm{AAS}$ optimization procedure

\begin{tabular}{|c|c|c|c|c|c|c|c|}
\hline Experiment & $\begin{array}{c}\text { Volume } \\
\text { Br-PADAP"/ } / \mu \mathrm{L}\end{array}$ & $\mathrm{pH}$ & $\begin{array}{c}\text { Volume Triton } \\
\mathrm{X}-114^{* * *} / \mu \mathrm{L}\end{array}$ & $\begin{array}{c}\text { Cd Integrated } \\
\text { absorbance/((s-1) }\end{array}$ & $\begin{array}{c}\mathrm{Pb} \text { Integrated } \\
\text { absorbance } /\left(\mathrm{s}^{-1}\right)\end{array}$ & Cd Peak Height & $\mathrm{Pb}$ Peak Height \\
\hline 1 & $450(1)$ & $9(0)$ & $550(0)$ & 5.41 & 2.84 & 1.30 & 0.37 \\
\hline 2 & $350(0.5)$ & $8(-0.5)$ & $50(-0.817)$ & 1.76 & 1.14 & 0.33 & 0.34 \\
\hline 3 & $350(0.5)$ & $8(-0.5)$ & $1050(0.817)$ & 1.81 & 2.32 & 0.25 & 0.24 \\
\hline 4 & $350(0.5)$ & $10(0.5)$ & $50(-0.817)$ & 6.08 & 2.26 & 1.16 & 0.55 \\
\hline 5 & $350(0.5)$ & $10(0.5)$ & $550(0.817)$ & 6.28 & 2.11 & 1.22 & 0.49 \\
\hline 6 & $250(0)$ & $7(-1)$ & $550(0)$ & 4.16 & 1.57 & 1.30 & 0.44 \\
\hline 7 & $250(0)$ & $9(0)$ & $550(0)$ & 4.87 & 3.47 & 1.17 & 0.73 \\
\hline 7 & $250(0)$ & $9(0)$ & $550(0)$ & 4.86 & 3.39 & 1.19 & 0.73 \\
\hline 7 & $250(0)$ & $9(0)$ & $550(0)$ & 4.86 & 3.21 & 1.17 & 0.73 \\
\hline 7 & $250(0)$ & $9(0)$ & $550(0)$ & 4.66 & 3.57 & 1.17 & 0.72 \\
\hline 8 & $250(0)$ & $11(1)$ & $550(0)$ & 1.10 & 0.40 & 0.04 & 0.08 \\
\hline 9 & $150(-0.5)$ & $8(-0.5)$ & $50(-0.817)$ & 0.68 & 1.65 & 0.26 & 0.40 \\
\hline 10 & $150(-0.5)$ & $8(-0.5)$ & $1050(0.817)$ & 5.42 & 1.33 & 1.12 & 0.24 \\
\hline 11 & $150(-0.5)$ & $10(0.5)$ & $50(-0.817)$ & 1.50 & 1.96 & 0.05 & 0.44 \\
\hline 12 & $150(-0.5)$ & $10(0.5)$ & $1050(0.817)$ & 2.56 & 1.26 & 0.40 & 0.30 \\
\hline 13 & $50(-1)$ & $9(0)$ & $550(0)$ & 1.74 & 2.55 & 0.32 & 0.56 \\
\hline
\end{tabular}

${ }^{*} 10^{-3} \mathrm{~mol} \mathrm{~L}{ }^{-1}$ Br-PADAP solution; ${ }^{* *}$ Triton X-114 5.0\% (m/v). 
Br-PADAD. Thus, the relationship between the $\mathrm{pH}$ and the Triton ${ }^{\circledR} \mathrm{X}-114$ solution was chosen to demonstrate the results. Figures 1 and 2 illustrate the maximum points. The application of Lagrange's criterion ${ }^{27}$ to each equation gave the $\mathrm{Cd}$ and $\mathrm{Pb}$ critical values. For the optimized cloud point extraction procedure, it was used a volume of $245 \mu \mathrm{L}$ of complexing agent solution (Br-PADAP), $765 \mu \mathrm{L}$ of Triton ${ }^{\circledR} \mathrm{X}-114$ solution, and $\mathrm{pH} 9$ for $\mathrm{Cd}$, while for $\mathrm{Pb}, 295 \mu \mathrm{L}$ of Br-PADAP, $580 \mu \mathrm{L}$ of Triton ${ }^{\circledR} \mathrm{X}-114$, and $\mathrm{pH} 9$ were used. These values were used considering the interactions of the three variables. These experimental conditions were applied in further experiments for determination of $\mathrm{Cd}$ and $\mathrm{Pb}$ in tobacco samples. The final concentrations of the Br-PADAP solution were $1.8 \times 10^{-2}$ and $2.1 \times 10^{-2} \mathrm{mmol} \mathrm{L}^{-1}$, and for the Triton ${ }^{\circledR}$ $\mathrm{X}-114$ solution, 0.36 and $0.31 \% \mathrm{~m} / \mathrm{v}$, for $\mathrm{Cd}$ and $\mathrm{Pb}$, respectively.

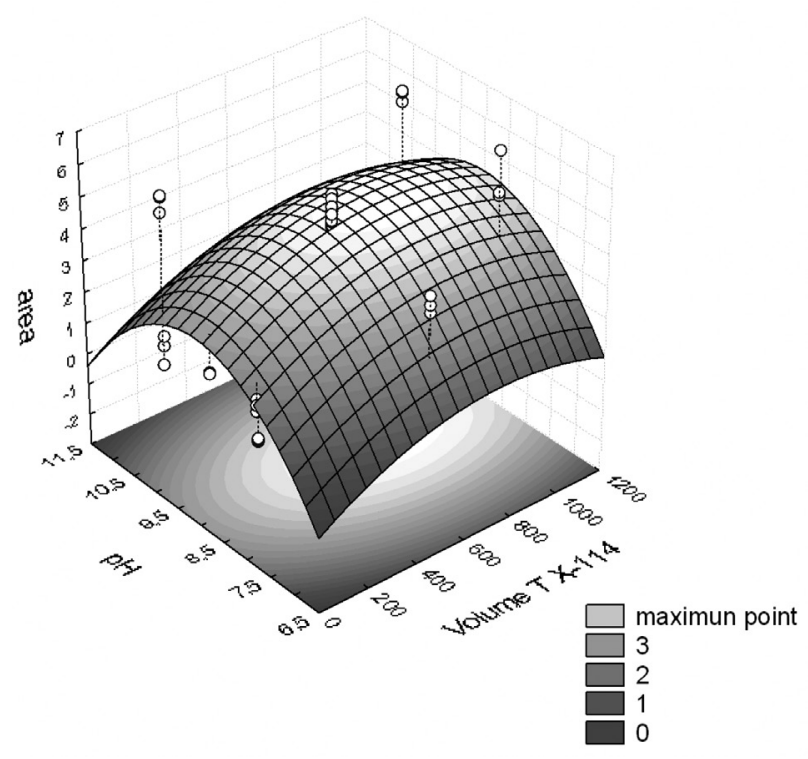

Figure 1. Surface response for peak area integrated absorbance of $\mathrm{Cd}$ $\left[\mathrm{pH} v s\right.$. Vol TX $\left.\left(\operatorname{Triton}^{\circledR} \mathrm{X}-114\right)\right]$.

\section{Analytical characteristics}

Figures of merit for $\mathrm{Cd}$ and $\mathrm{Pb}$ measurements were obtained by TS-FF-AAS using the optimized experimental conditions. The results are presented in Table 2. The limits of detection ( 3 standard deviations of the blank/slope) and quantification (10 standard deviations of the blank/slope) were determined from 10 blank readings. The $\mathrm{Cd}$ and $\mathrm{Pb}$ LOD's found using CP preconcentration and TS-FF-AAS were 4.0 and $13 \mu \mathrm{g} \mathrm{kg}^{-1}$, respectively. The detectability improvement factors for $\mathrm{Cd}$ and $\mathrm{Pb}$ were 62 and 158 , respectively, when comparing the proposed method $($ CPE + TS-FF-AAS $)$ with conventional FAAS. The

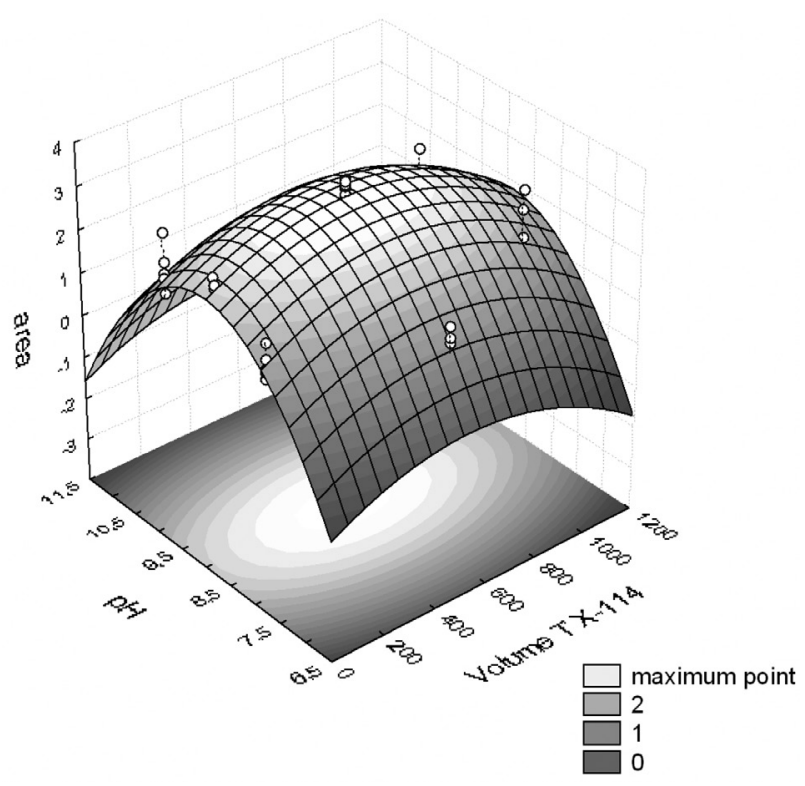

Figure 2. Surface response for peak area integrated absorbance of $\mathrm{Pb}$ $\left[\mathrm{pH} v s\right.$. Vol TX (Triton $\left.\left.^{\circledast} \mathrm{X}-114\right)\right]$.

repeatability for $\mathrm{Cd}$ and $\mathrm{Pb}, 3.1$ and $0.7 \%$, respectively, was determined by successive measurements of the standard solutions $\left(25 \mu \mathrm{g} \mathrm{L}{ }^{-1}\right)$. The linear dynamic range varied from 0.08 to $25 \mu \mathrm{g} \mathrm{L} \mathrm{L}^{-1}$ for $\mathrm{Cd}$, and from 0.26 to $250 \mu \mathrm{g} \mathrm{L}^{-1}$ for $\mathrm{Pb}$.

Table 2. Analytical characteristics of the $\mathrm{Cd}$ and $\mathrm{Pb}$ measurements by TS-FF-AAS

\begin{tabular}{lcc}
\hline & $\mathrm{Cd}$ & $\mathrm{Pb}$ \\
\hline Linear dynamic range $/\left(\mu \mathrm{g} \mathrm{L}{ }^{-1}\right)$ & $0.08-25$ & $0.26-250$ \\
Linear correlation coefficient & 0.9985 & 0.9979 \\
R.S.D./(\%) & 3.1 & 0.7 \\
$\mathrm{LOD} /\left(\mu \mathrm{g} \mathrm{kg}^{-1}\right)$ & 4.0 & 13.0 \\
$\mathrm{LOQ} /\left(\mu \mathrm{g} \mathrm{kg}^{-1}\right)$ & 14.0 & 41.0 \\
Improvement factor & 62 & 158 \\
\hline
\end{tabular}

\section{Accuracy and recovery studies}

To evaluate the accuracy of the developed procedure, $\mathrm{Cd}$ and $\mathrm{Pb}$ were determined in the two standard reference materials (Peach leaves-GBW08501 and Tea leavesGBW08505). The results are presented in Table 3. No difference was observed for $\mathrm{Cd}$ and $\mathrm{Pb}$ in either sample by $t$-Student test at $95 \%$ confidence level, except for the $\mathrm{Pb}$ content in tea leaves, which was in agreement at $99 \%$ confidence level.

Recovery of $\mathrm{Cd}$ and $\mathrm{Pb}$ in different tobacco samples was evaluated in triplicate at two levels by adding 2.5 and $5.0 \mu \mathrm{g} \mathrm{L}^{-1}$ of both elements to commercial samples. The results are given in Table 4 . Recovery ranged from 93 to 
Table 3. Cadmium and lead determinations in two standard reference materials by TS-FF-AAS $($ mean \pm standard deviation, $n=4, \mathrm{P}=0.05)$

\begin{tabular}{lcccc}
\hline & \multicolumn{2}{c}{ Certified values $/\left(\mu \mathrm{g} \mathrm{g}^{-1}\right)$} & \multicolumn{2}{c}{ Obtained values $/\left(\mu \mathrm{g} \mathrm{g}{ }^{-1}\right)$} \\
$\mathrm{Cd}$ & $\mathrm{Pb}$ & $\mathrm{Cd}$ & $\mathrm{Pb}$ \\
\hline Tea leaves- GBW08505 & $0.032 \pm 0.005$ & $1.06 \pm 0.10$ & $0.029 \pm 0.002$ & $1.45 \pm 0.22^{*}$ \\
Peach leaves- GBW08501 & $0.018 \pm 0.008$ & $0.99 \pm 0.08$ & $0.019 \pm 0.009$ & $1.23 \pm 0.39$ \\
\hline
\end{tabular}

$* \mathrm{P}=0.01$

Table 4. Recovery experiments for $\mathrm{Cd}$ and $\mathrm{Pb}$ in different tobacco samples $(\mathrm{n}=3)$

\begin{tabular}{|c|c|c|c|c|c|c|}
\hline \multirow{2}{*}{ Sample } & \multicolumn{3}{|c|}{$\mathrm{Cd}$} & \multicolumn{3}{|c|}{$\mathrm{Pb}$} \\
\hline & Added/( $\left.\mu g \mathrm{~L}^{-1}\right)$ & Found/ $\left(\mu \mathrm{g} \mathrm{L}^{-1}\right)$ & Recovery/ (\%) & Added/ $\left(\mu \mathrm{g} \mathrm{L}^{-1}\right)$ & Found/ $\left(\mu \mathrm{g} \mathrm{L}^{-1}\right)$ & Recovery/ (\%) \\
\hline regular & 2.5 & 10.6 & 98.2 & 2.5 & 5.1 & 94.6 \\
\hline regular & 5.0 & 12.9 & 94.2 & 5.0 & 7.4 & 93.1 \\
\hline straw & 2.5 & 15.1 & 102.5 & 2.5 & 22.7 & 92.5 \\
\hline straw & 5.0 & 17.6 & 101.3 & 5.0 & 25.2 & 96.5 \\
\hline roll & 2.5 & 16.0 & 95.6 & 2.5 & 30.3 & 105.3 \\
\hline roll & 5.0 & 18.3 & 93.2 & 5.0 & 32.9 & 106.6 \\
\hline
\end{tabular}

$107 \%$ for both analytes. No matrix effects were observed in the optimized procedure for the regular tobacco samples.

\section{Determination of $\mathrm{Cd}$ and $\mathrm{Pb}$ in tobacco samples}

After conventional acid digestion combining ash and wet digestion and optimized cloud point extraction using Br-PADAP as a complexing agent, commercial tobacco samples were analyzed using TS-FF-AAS. Cadmium and lead were not directly detected in tobacco acid digests by FAAS. Results are shown in Table 5. The samples named regular are common pack cigarettes bought at local shops, as previously mentioned. The found concentrations ranged from 0.148 to $0.380 \mu \mathrm{g} \mathrm{g}^{-1}$ for $\mathrm{Cd}$, and from 0.568 to $3.51 \mu \mathrm{g} \mathrm{g}^{-1}$ for $\mathrm{Pb}$. Regular HR cigarette presented the lowest $\mathrm{Cd}$ value, while CPC straw cigarette gave the highest $\mathrm{Pb}$ value. The standard deviations obtained are suitable, taking into account the various steps of the proposed procedure. It can be seen in Table 5 that the standard deviations were higher for $\mathrm{Cd}$ and $\mathrm{Pb}$ at lower concentrations than those obtained for tobacco samples with the highest analyte concentrations. The $\mathrm{Cd}$ and Pb LOD's obtained in this study were similar to literature values. ${ }^{17,21}$ Tarley et al. ${ }^{6}$ found a lower value for Cd employing TS-FF-AAS in combination with a minicolumn preconcentration system using multiwall carbon nanotubes. However, the method proposed here gave satisfactory results with good accuracy for the investigated samples.
Table 5. Determination of $\mathrm{Cd}$ and $\mathrm{Pb}$ in tobacco samples by TS-FF-AAS (mean \pm standard deviation, $\mathrm{n}=3$ )

\begin{tabular}{lcc}
\hline Tobacco samples & $\mathrm{Cd} /\left(\mu \mathrm{g} \mathrm{g}^{-1}\right)$ & $\mathrm{Pb} /\left(\mu \mathrm{g} \mathrm{g}^{-1}\right)$ \\
\hline DR regular & $0.227 \pm 0.060$ & $0.740 \pm 0.077$ \\
DG regular & $0.313 \pm 0.097$ & $3.00 \pm 0.04$ \\
HR regular & $0.148 \pm 0.036$ & $3.00 \pm 0.02$ \\
C regular & $0.228 \pm 0.012$ & $3.07 \pm 0.05$ \\
T regular & $0.213 \pm 0.028$ & $2.99 \pm 0.04$ \\
CPP straw & $0.349 \pm 0.005$ & $0.568 \pm 0.040$ \\
CPC straw & $0.345 \pm 0.069$ & $3.51 \pm 0.03$ \\
CPVJ straw & $0.221 \pm 0.009$ & $3.11 \pm 0.05$ \\
CPD straw & $0.242 \pm 0.063$ & $3.08 \pm 0.05$ \\
FRF roll & $0.380 \pm 0.020$ & $0.769 \pm 0.040$ \\
FRM roll & $0.213 \pm 0.032$ & $3.06 \pm 0.14$ \\
FRf roll & $0.235 \pm 0.027$ & $3.14 \pm 0.05$ \\
FRG roll & $0.189 \pm 0.022$ & $2.94 \pm 0.05$ \\
\hline
\end{tabular}

\section{Conclusions}

Cadmium and lead were determined in tobacco samples by TS-FF-AAS technique after acid digestion and optimized cloud point preconcentration using Br-PADAP as a complexing agent. The optimization of the cloud point preconcentration conditions by Doehlert design improved the sensitivity for determination of $\mathrm{Cd}$ and $\mathrm{Pb}$ using a small number of experiments and employing reduced reagent 
volumes. The association of TS-FF-AAS with cloud point preconcentration led to a gain about 62-158-fold higher than that obtained by FAAS. The proposed procedure may be applicable to other elements present in low concentrations in tobacco samples and to quality control.

\section{Acknowledgments}

The authors are grateful to Pró-Reitoria de Pesquisa da Universidade Federal de Minas Gerais (PRPQ-UFMG) for the financial support. F.P.A. is thankful for the fellowship provided by Coordenação de Aperfeiçoamento de Pessoal de Nível Superior (CAPES).

\section{References}

1. Petrucelli, G. A.; Poppi, R. J.; Mincato, R. L.; Pereira-Filho, E. R.; Talanta 2007, 71, 620.

2. Borges, D. L. G.; Veiga, M. A. M. S.; Frescura, V. L. A.; Welz, B.; Curtis, A. J.; J. Anal. At. Spectrom. 2003, 18, 501.

3. Bernhard, D.; Rossmann, A.; Wick, G.; IUBMB Life 2005, 57, 805.

4. Wu, P.; Liu, R.; Berndt, H.; Lv, Y.; Hou, X.; J. Anal. At. Spectrom. 2008, 23, 37.

5. Silva, M. F.; Cerutti, E. S.; Martinez, L. D.; Microchim. Acta 2006, 155, 349.

6. Tarley, C. R. T.; Barbosa, A. F.; Segatelli, M. G.; Figueiredo, E. C.; Luccas, P. O.; J. Anal. At. Spectrom. 2006, 21, 1305.

7. Coelho, L. M.; Arruda, M. A. Z.; Spectrochim. Acta, Part B 2005, 60, 743 .

8. Bezerra, M. A.; Arruda, M. A. Z.; Ferreira, S. L. C.; Appl. Spectrosc. Rev. 2005, 40, 269.

9. Manzoori, J. L.; Abdolmohammad-Zadeh, H.; Amjadi, M.; Talanta 2007, 71, 582.

10. Bezerra, M. A.; Bruns, R. E.; Ferreira, S. L. C.; Anal. Chim. Acta 2006, 580, 251.
11. Gáspár, A.; Berndt, H.; Spectrochim. Acta Part B 2000, 55, 587.

12. Wu, P.; Zhang, Y.; Lv, Y.; Hou, X.; Spectrochim. Acta, Part B 2006, 61, 1310.

13. Nascentes, C. C.; Arruda, M. A. Z.; Nogueira, A. R.; Nóbrega, J. A.; Talanta 2004, 64, 912.

14. Davies, J.; Berndt, H.; Anal. Chim. Acta 2003, 479, 215.

15. Gáspár, A.; Széles, E.; Berndt, H.; Anal. Bioanal. Chem. 2002, $372,136$.

16. González, E.; Ahumada, R.; Medina, V.; Neira, J.; González, U.; Quim. Nova 2004, 27, 873.

17. Rosini, F.; Nascentes, C. C.; Neira, J. Y.; Nóbrega, J. A.; Talanta 2007, 73, 845 .

18. Pereira-Filho, E. R.; Berndt, H.; Arruda, M. A. Z.; J. Anal. At. Spectrom. 2002, 17, 1308.

19. Nascentes, C. C.; Kamogawa, M. Y.; Fernandes, K. G.; Arruda, M. A. Z.; Nogueira, A. R. A.; Nóbrega, J. A.; Spectrochim. Acta, Part B 2005, 60, 749.

20. Donati, G. L.; Nascentes, C. C.; Nogueira, A. R. A.; Arruda, M. A. Z.; Nóbrega, J. A.; Microchem. J. 2006, 82, 189.

21. Amorim, F. A. C.; Bezerra, M. A.; Microchim. Acta 2007, 159, 183.

22. Ivanova, E.; Berndt, H.; Pulvermacher, E.; J. Anal. At. Spectrom. 2004, 19, 1507.

23. Manickum, C. K.; Verbeek, A. A.; J. Anal. At. Spectrom. 1994, 19, 227.

24. Manzoori, J. L.; Karim-Nezhad, G.; Anal. Chim. Acta 2004, $521,173$.

25. Teófilo, R. F.; Ferreira, M. M. C.; Quim. Nova 2006, 29, 338.

26. Ferreira, S. L. C.; Santos, W. N. L.; Quintella, C. M.; Neto, B. B.; Bosque-Sendra, J. M.; Talanta 2004, 63, 1061.

27. Ferreira, S. L. C.; Santos, H. C.; Fernandes, M. S.; Carvalho, M. S.; J. Anal. At. Spectrom. 2002, 17, 115.

28. Statistica for Windows, Statsoft: Tulsa, OK, 1999.

Received: September 28, 2008 Web Release Date: August 20, 2009 